\begin{abstract}
Anna Falana-Jafra
Instytut Filologii Polskiej Uniwersytetu Humanistyczno-Przyrodniczego im. Jana Długosza w Częstochowie
\end{abstract}

\title{
Pojęcie przestępstwa lingwistycznego i jego typologie
}

\section{Uwagi wprowadzające}

Język naturalny rozpatrywany jest na płaszczyźnie naukowej z rozmaitych perspektyw - jako narzędzie komunikacji, ekspresji, estetyki, poznania itd. Paradygmat badawczy uzależniony jest od specyfiki dyscypliny naukowej, która język analizuje i opisuje. Rzadko jednak dostrzegana jest rola języka jako środka służącego do dokonywania czynów przez prawo niedozwolonych. $\mathrm{Na}$ gruncie zarówno polskiego systemu prawnego, jak i systemów prawnych wielu innych krajów artykułowanie pewnych słów bądź milczenie w określonych kontekstach sytuacyjnych spotkać się może z reakcją organów ścigania. Język naturalny w tym ujęciu stanowi zatem potencjalne, specyficzne narzędzie, które może zostać wykorzystane do łamania porządku prawnego, dostępne dla większości ludzi wyposażonych w dar mówienia i pisania.

Gałęzią prawa ukierunkowaną na zapewnienie spokoju i porządku publicznego jest prawo karne materialne. W czasie wytyczania dla obywateli pola dozwolonych normatywnie zachowań posługuje się ono z jednej strony prewencją, z drugiej zaś represją [Gardocki 2019: 22]. Jak wskazuje Andrzej Marek,

nazwa „prawo karne” określa jedną z gałęzi systemu prawa obowiązującego $\mathrm{w}$ państwie. Z punktu widzenia formalno-prawnego prawem karnym jest zespół norm prawnych definiujących czyny zabronione pod groźbą kary oraz określających zasady odpowiedzialności za te czyny. Najistotniejszym elementem tej definicji jest kara, będąca przewidzianą przez prawo ujemną reakcją na czyn zabroniony. Oznacza to zarazem, iż drugim elementem dystynktywnym 
jest czyn naganny, społecznie szkodliwy, z tego powodu bowiem zostaje on zabroniony pod groźbą kary. [Konarska-Wrzosek, Marek 2019: 19]

Dopełnieniem prawa karnego materialnego jest prawo karne procesowe, regulujące w sposób szczegółowy role poszczególnych podmiotów w postępowaniu karnym oraz pracę organów wymiaru sprawiedliwości [Zagrodnik i in. 2019: 19].

Prawo karne materialne pełni w Polsce funkcje: sprawiedliwościową, ochronną i kompensacyjną [Wróbel, Zoll 2014: 61-63]. Jego zakres obejmuje przepisy zawarte nie tylko w Kodeksie karnym [k.k.], ale również w Kodeksie karnym skarbowym [k.k.s.] oraz w licznych ustawach szczególnych. Do fundamentalnych jego zasad zalicza się wykształconą w czasach oświecenia regułę nullum crimen sine lege, zgodnie z którą za przestępstwo może zostać uznany jedynie czyn, który był zabroniony przez ustawę w momencie jego popełnienia [Konarska-Wrzosek, Marek 2019: 41-42]. Spór o związek pomiędzy moralnością a prawem ma szczególne znaczenie właśnie na kanwie prawa karnego materialnego, które wprost odnosi się do zachowań społecznie niepożądanych, godzących w podstawowe dobra tak w ujęciu ogólnopaństwowym czy ogólnospołecznym, jak indywidualnym [Bojarski, Giezek, Sienkiewicz 2020: 25].

Przepisy prawa karnego materialnego konstytuujące czyny przestępcze co do zasady charakteryzują się trójdzielną strukturą, w ramach której wyróżnić można hipotezę normy, jej dyspozycję oraz sankcję [Zieliński 2017: 31-32]. Hipoteza to możliwie najbardziej abstrakcyjne wskazanie podlegających penalizacji stanów faktycznych, dyspozycja - nakaz określonych działań bądź zaniechań, natomiast sankcja - określenie prawnokarnych skutków zachowań niezgodnych z normą [Zieliński 2017: 32]. Przedstawiciele nauki prawa karnego materialnego tworzą rozmaite typologie przestępstw, kwalifikując je do poszczególnych kategorii na podstawie wyodrębnionych uprzednio kryteriów. Niekiedy czyni to również sam ustawodawca, np. wprowadzając podział ze względu na społeczną wagę i szkodliwość przestępstw (przestępstwa będące zbrodniami i przestępstwa będące występkami) czy na rodzaj dobra prawnego, przeciwko któremu ludzkie działania są wymierzane (przestępstwa przeciwko życiu i zdrowiu, przestępstwa przeciwko bezpieczeństwu w komunikacji, przestępstwa przeciwko obrotowi gospodarczemu i interesom majątkowym w obrocie cywilnoprawnym etc.).

Prezentowane poniżej rozważania mają charakter wprowadzający do tematyki; ich celem jest zaakcentowanie istnienia specyficznego zjawiska językowego, jakim są przestępstwa lingwistyczne, a także wstępne opracowanie ich 
typologii. Badania zostaną poszerzone i uszczegółowione; mam nadzieję, że uda się je zebrać i przedstawić w formie monografii naukowej.

\section{Charakterystyka przestępstw lingwistycznych}

Szczególnym typem czynów zabronionych są przestępstwa, które mogą zostać popełnione przez wypowiedzenie lub napisanie pewnych słów czy zwrotów albo przez zachowanie milczenia wówczas, gdy wypowiedź jest przez przepisy prawa nakazana. Do ich zrealizowania nie jest zatem konieczne posługiwanie się narzędziami sprawczymi innymi niż aparat mowy czy podstawowe przyrządy piśmiennicze. Na potrzeby dalszych rozważań przestępstwa tego rodzaju określać będziemy mianem przestępstw lingwistycznych - łac. linguae crimines. Nie doczekały się one, jak dotąd, zbiorczego i wyczerpującego opracowania teoretycznego - zarówno prawniczego, jak i językoznawczego. Na ogół badane są z perspektywy tych dwóch nauk w ujęciu indywidualnym.

Charakterystykę linguae crimines rozpocząć należy od spostrzeżenia, iż w świetle prawa polskiego podlegają one takiemu samemu katalogowi kar i środków karnych jak wszystkie pozostałe czyny zabronione. Świadczy to o uznaniu przez ustawodawcę języka ludzkiego za narzędzie wykonawcze równosilne z innymi - np. z niebezpiecznymi przedmiotami - w zakresie zdolności do wywoływania negatywnych skutków społecznych. Temu aksjologicznemu zbliżeniu nie stoją na przeszkodzie różnice pomiędzy przestępstwami o charakterze lingwistycznym oraz przestępstwami niemającymi tegoż charakteru, polegające na zakresie i specyfice zmian wprowadzanych w obiektywnej rzeczywistości. Dokonanie przestępstw lingwistycznych nie implikuje np. - bo ze swej istoty nie może implikować - fizycznych obrażeń czy cielesnych urazów ofiar, a jedynie, niekiedy, urazy psychiczne, takie jak np. utrata poczucia bezpieczeństwa czy poczucia własnej wartości. Bywa jednak, że skutki tego typu w ogóle nie muszą wystąpić - adresatom słowa do nich kierowane mogą być zupełnie obojętne, a pomimo tego czyn spotka się z represją karną. Dzieje się tak w konsekwencji uznania przez ustawodawcę, że dana wypowiedź narusza dobra nie tyle indywidualne, ile ogólnospołeczne, choć jednocześnie nie powoduje żadnych realnych zmian w rzeczywistości. Rozpatrzymy w tym miejscu przestępstwo nawoływania do popełnienia zbrodni, które nie spotka się z żadną reakcją ze strony nawoływanych osób - żadna z nich wezwaniu nie ulegnie, być może nawet nie pomyśli o tym, by się do niego zastosować. Użycie określonych słów w określonych kontekstach sytuacyjnych nie musi zatem za sobą pociągać jakichkolwiek skutków natury fizycznej, by w świetle obowiązującego prawa mogło zostać uznane za zachowanie przejawiające wszystkie ustawowe cechy i właściwości czynu przestępczego. 
Wykorzystanie języka naturalnego jako swoistego narzędzia wykonawczego służącego popełnianiu przestępstw jest jedną z sytuacji, w których „wygłoszenie wypowiedzi jest wykonaniem jakiejś czynności, jest czymś, o czym nie myśli się normalnie jako tylko o powiedzeniu czegoś" [Austin 1993: 555]. Kreacyjna rola języka powoduje, że artykulacja określonych słów czy wyrażeń tworzy nowe realia, w których samo użycie języka urasta do rangi faktu prawnego. Przez pojęcie faktu prawnego w nauce prawa polskiego rozumie się „,każde zdarzenie, które powoduje powstanie, ustanie lub zmianę treści stosunku prawnego, czyli każde takie zdarzenie, które wywołuje jakieś skutki prawne" [Morawski 2004: 228]. W wypadku popełnienia przestępstwa najdonioślejszym skutkiem prawnym bez wątpienia jest narażenie sprawcy na odpowiedzialność karną, a więc na sankcje stosowane w sposób władczy (choć nie arbitralny) przez władzę państwową. Penalizowane przez system prawa słowa i wyrażenia mają zatem - z językoznawczego punktu widzenia charakter wypowiedzi performatywnych. Zauważyć należy jednak, że przy rozpatrywaniu linguae crimines owa performatywność ulega rozszerzeniu także na sferę milczenia sprawcy, które - podobnie jak formułowanie ustnych czy pisemnych wypowiedzi - rodzić może w świetle obowiązujących przepisów określone skutki prawne. Tak jest np. w wypadku przestępstwa składania fałszywych zeznań, które może zostać zrealizowane zarówno przez wypowiedzi niezgodne z prawdą, jak i przez zatajenie prawdy - przemilczenie faktów z nią zgodnych; podobnie rzecz się ma w wypadku przestępstwa polegającego na zaniechaniu obowiązku denuncjacji, a więc niezwłocznego poinformowania organów ścigania o niektórych gatunkowo ciężkich czynach zabronionych popełnionych przez inne osoby. Zasadny jest zatem wniosek, iż na płaszczyźnie linguae crimines mówić możemy zarówno o performatywności językowej czynnej, jak i o performatywności językowej biernej, przejawiającej się w milczeniu sprawcy.

Jak się ponadto wydaje, w przypadku linguae crimines mówić można wyłącznie o umyślnej formie zawinienia, a więc o świadomym sprzeniewierzaniu się przez sprawcę porządkowi prawnemu. Polskie prawo karne materialne wyróżnia dwie postaci zawinienia - winę umyślą oraz winę nieumyślną. Zawinienie jest warunkiem koniecznym przypisania sprawcy odpowiedzialności karnej. Artykuł 3 Kodeksu karnego wprost stanowi, że „nie popełnia przestępstwa sprawca czynu zabronionego, jeżeli nie można mu przypisać winy w czasie czynu" [art. 3 k.k.]. Prawo przewiduje więc sytuacje, w których - z przyczyn obiektywnych - pomimo nagannego i niezgodnego z przepisami zachowania się sprawcy nie można zastosować względem niego sankcji [Stefański, red. 2020: 22-23]. Wśród czynników wpływających na taką 
kwalifikację wymienić można niedojrzałość emocjonalną związaną z młodym wiekiem, chorobę psychiczną czy uzależnienie od alkoholu bądź substancji psychotropowych. Osoba taka może operować językiem w sposób nieświadomy czy też niecałkowicie uświadomiony; może także operować językiem w sposób odmienny od przez siebie zamierzonego, a więc błędnie w stosunku do przejawianych motywacji. Z tych samych względów może odstępować od wypowiedzi wówczas, gdy prawo jej wymaga. Jednak pomimo wypowiedzenia słów, naniesienia ich na nośnik informacji albo przemilczenia wypadki tego typu nie będą klasyfikowane jako przestępstwa lingwistyczne, a tym samym wykluczone będzie stosowanie względem sprawców represji karnej. Osoba zdolna do ponoszenia odpowiedzialności karnej musi być bowiem również zdolna do świadomego, przemyślanego użycia języka, który będzie narzędziem wykonawczym w pełni uzależnionym od jej woli i nad którym będzie ona posiadała totalną, przyrodzoną kontrolę. Wynika to z biologicznej specyfiki ludzkiego aparatu mowy oraz z natury reakcji cielesnych, na skutek których słowa są kodowane w języku pisanym na nośnikach informacji. Zachowania te u ludzi zdrowych psychofizycznie nie przebiegają w sposób odruchowy, lecz są następstwem analizy myślowej [Everett 2018: 60]. Na gruncie prawnym powinny być zatem kwalifikowane jako przestępstwa umyślne, a tym samym jednoznacznie negatywnie oceniane przez ustawodawcę $\mathrm{w}$ aspekcie aksjologicznym.

W tym miejscu zarysowuje się problem linguae crimines popełnianych pod wpływem silnych emocji. Nie wdając się w rozważania szczegółowe, zaznaczyć jedynie należy, iż polskie prawo karne materialne uwzględnia na ogół nie stan emocjonalny sprawcy towarzyszący mu w chwili popełnienia czynu zabronionego, lecz jego utrwalone „właściwości i warunki osobiste”, na które składać się może wrodzona bądź nabyta skłonność do przejawiania nieadekwatnych, w tym w szczególności wyolbrzymionych reakcji emocjonalnych [Stanik 2013: 430].

Podsumowując, przestępstwo lingwistyczne zdefiniować należy jako przestępstwo o charakterze umyślnym, którego co najmniej jeden z przewidzianych przez ustawodawcę sposobów realizacji polega na autonomicznym działaniu:

a) ustnej artykulacji określonych słów, zwrotów czy wyrażeń,

b) naniesieniu ich na nośniki informacji za pomocą pisma albo

c) zachowaniu milczenia w sytuacjach, gdy wypowiedź jest przez prawo wymagana.

Wśród tak zdefiniowanych linguae crimines wyróżnić można wiele podtypów, w zależności od przyjętego kryterium. 


\section{Wybrane typologie przestępstw lingwistycznych}

Zaproponowane powyżej ujęcie przestępstwa lingwistycznego kładzie nacisk na istnienie w przepisie prawnym co najmniej jednego językowego sposobu realizacji danego czynu. W pierwszej kolejności wyróżnić należy wobec tego przestępstwa lingwistyczne wyłączne i przestępstwa lingwistyczne niewyłączne. Zastosowanym kryterium rozróżnienia jest właśnie przewidziany przez ustawodawcę charakter czynności wykonawczych sprawcy. Istotą przestępstw lingwistycznych wyłącznych będzie zatem to, że mogą one zostać popełnione jedynie na skutek użycia bądź zaniechania użycia języka; w ramach przestępstw lingwistycznych niewyłącznych ustawodawca alternatywnie do zachowań językowych dopuszcza natomiast inne ludzkie działania. Przypatrzmy się następującym przykładom zaczerpniętym z aktualnie obowiązującego Kodeksu karnego:

Kto pomawia inną osobę, grupę osób, instytucję, osobę prawną lub jednostkę organizacyjną niemającą osobowości prawnej o takie postępowanie lub właściwości, które mogą poniżyć ją w opinii publicznej lub narazić na utratę zaufania potrzebnego dla danego środowiska, zawodu lub rodzaju działalności, podlega grzywnie albo karze ograniczenia wolności. [art. 212 par. 1 k.k.]

Kto grozi innej osobie popełnieniem przestępstwa na jej szkodę lub szkodę osoby najbliższej, jeżeli groźba wzbudza w zagrożonym uzasadnioną obawę, że będzie spełniona, podlega grzywnie, karze ograniczenia wolności albo pozbawienia wolności do lat 2. [art. 190 par. 1 k.k.]

Przestępstwo zniesławienia penalizowane w art. 212 k.k. może zostać popełnione wyłącznie za pomocą języka. Do wniosku takiego uprawnia użycie przez ustawodawcę określenia pomawiać, odnoszącego się wprost do wypowiadania określonych słów i stanowiącego synonim wyrażeń „oskarżać, bezpodstawnie obciążać kogoś winą lub przypisywać komuś złe czyny i złe zamiary" [Kurzowa i in. 2008: 418]. Przestępstwo polegające na formułowaniu gróźb karalnych może zostać z kolei zrealizowane na skutek zarówno niezgodnego z prawem użycia języka, jak i szeregu innych działań, np. wykonania pod adresem ofiary gestów wskazujących na czynione względem niej plany [Nazar-Gutowska 2012: 75]. Warunkiem sine qua non przestępstwa lingwistycznego jest to, by przynajmniej jedna z przewidzianych przez ustawodawcę czynności wykonawczych polegała na autonomicznym (a więc w pełni samodzielnym, rozpatrywanym w oderwaniu od innych zachowań) użyciu języka mówionego bądź pisanego albo zaniechaniu tegoż użycia. Oba wskazane powyżej prze- 
stępstwa warunek ten niewątpliwie spełniają, przy czym w wypadku drugiego $\mathrm{z}$ nich użycie języka nie jest jedynym sposobem przewidzianej przez prawo drogi realizacji.

Kolejna typologia linguae crimines opiera się na linii podziału: artykulacja (zapis) - milczenie. Pozwala ona na włączenie do kategorii przestępstw lingwistycznych także językowych zachowań biernych, polegających na powstrzymaniu się - pomimo istnienia normatywnego obowiązku - od mowy bądź pisma. Klasycznym przykładem przestępstwa popełnianego milczeniem jest wspomniane już wcześniej niedochowanie obywatelskiej powinności denuncjacji:

Kto, mając wiarygodną wiadomość o karalnym przygotowaniu albo usiłowaniu lub dokonaniu czynu zabronionego określonego w art. 118, art. 118a, art. $120-124$, art. 127 , art. 128, art. 130, art. 134, art. 140, art. 148, art. 156, art. 163, art. 166, art. 189, art. $197 \S 3$ lub 4, art. 198, art. 200, art. 252 lub przestępstwa o charakterze terrorystycznym, nie zawiadamia niezwłocznie organu powołanego do ścigania przestępstw, podlega karze pozbawienia wolności do lat 3. [art. 240 par. 1 k.k.]

Analiza obecnie obowiązujących w Polsce przepisów karnych upoważnia do stwierdzenia, że milczenie jako przestępcza czynność sprawcza stanowi często alternatywną względem użycia języka formę wykonawczą. Przykładem tego zabiegu legislacyjnego może być ustawowa konstrukcja przestępstwa składania fałszywych zeznań, funkcjonującego w Kodeksie karnym w następującym brzmieniu:

Kto, składając zeznanie mające służyć za dowód w postępowaniu sądowym lub $\mathrm{w}$ innym postępowaniu prowadzonym na podstawie ustawy, zeznaje nieprawdę lub zataja prawdę, podlega karze pozbawienia wolności od 6 miesięcy do lat 8 . [art. 233 par. 1 k.k.]

Forma przestępcza „z użycia języka” zestawiona została na zasadzie koniunkcji z formą „,z milczenia”, a zatem zeznania mogą zostać uznane za fałszywe na skutek zarówno świadomego użycia języka, jak i świadomej odmowy jego użycia przez sprawcę.

Typologia przestępstw lingwistycznych jednokrotnych i wielokrotnych oparta jest z kolei na relacji między czynnością wykonawczą a czasem jej realizacji. I tak o przestępstwach jednokrotnych mówić można wówczas, gdy do stwierdzenia ich popełnienia, a tym samym zastosowania wobec sprawcy sankcji karnych wystarczające jest jednokrotne użycie języka bądź jednokrotne 
zaniechanie jego użycia. Przestępstwa lingwistyczne wielokrotne charakteryzują się natomiast wymaganą prawnie powtarzalnością czynności wykonawczych, wymuszającą istnienie rozciągłej perspektywy czasowej. Prześledźmy następujące przykłady:

Kto, przed organem powołanym do ścigania lub orzekania w sprawach o przestępstwo, w tym i przestępstwo skarbowe, wykroczenie, wykroczenie skarbowe lub przewinienie dyscyplinarne, fałszywie oskarża inną osobę o popełnienie tych czynów zabronionych lub przewinienia dyscyplinarnego, podlega grzywnie, karze ograniczenia wolności albo pozbawienia wolności do lat 2. [art. 234 k.k.]

Kto przez uporczywe nękanie innej osoby lub osoby jej najbliższej wzbudza u niej uzasadnione okolicznościami poczucie zagrożenia, poniżenia lub udręczenia lub istotnie narusza jej prywatność, podlega karze pozbawienia wolności od 6 miesięcy do lat 8. [art. 190a par. 1 k.k.]

Już wstępna analiza językowa wyżej zacytowanych przepisów pozwala dostrzec, że w strukturę normatywną przestępstwa powszechnie zwanego stalkingiem wkomponowany został przez ustawodawcę element temporalności, wynikający z użycia wyrazu uporczywie. Jak trafnie wskazał Sąd Apelacyjny we Wrocławiu w wyroku z 19 lutego 2014 roku,

[o] uporczywym zachowaniu się sprawcy świadczyć będzie z jednej strony jego szczególne nastawienie psychiczne, wyrażające się w nieustępliwości nękania, tj. trwaniu w swego rodzaju uporze, mimo próśb i upomnień pochodzących od pokrzywdzonego lub innych osób o zaprzestanie przedmiotowych zachowań, z drugiej natomiast strony - dłuższy upływ czasu, przez który sprawca je podejmuje. Skutkiem zachowania się sprawcy musi być wytworzenie u pokrzywdzonego uzasadnionego poczucia zagrożenia lub poczucia istotnego naruszenia jego prywatności ${ }^{1}$.

W przeciwieństwie do przestępstwa uporczywego nękania przestępstwo lingwistyczne polegające na formułowaniu fałszywych oskarżeń względem innych osób może być natomiast dokonane jednorazowo - przez jednokrotne tylko użycie języka w wymaganym przez ustawę kontekście sytuacyjnym.

1 Wyrok Sądu Apelacyjnego we Wrocławiu z dnia 19 lutego 2014 r., II AKa 18/14, LEX nr 1439334. 
Kolejna typologia linguae crimines związana jest z akcentowanym już uprzednio podziałem na bezpośrednie i pośrednie użycie słów czy wyrażeń. $\mathrm{Z}$ użyciem bezpośrednim mamy do czynienia wówczas, gdy sprawca nie cytuje wypowiedzi innych osób, lecz w celach przestępczych formułuje własne. Użycie pośrednie polega natomiast na popełnieniu przestępstwa przez powołanie się na słowa innych. Jak się wydaje, przestępstwa lingwistyczne pośrednie zrealizowane mogą zostać jedynie wówczas, gdy możliwość taka została przewidziana przez ustawodawcę dla przestępstw bezpośrednich. Polskie prawo karne materialne nie zna bowiem osobnej kategorii „przestępstw z cytatów”. Bogactwo rzeczywistości upoważnia jednak do stwierdzenia, że lingwistyczne przestępstwa pośrednie są normatywnie możliwe. Powołajmy się na następujące przykłady:

Kto publicznie znieważa Naród lub Rzeczpospolitą Polską, podlega karze pozbawienia wolności do lat 3. [art. 133 k.k.]

Kto publicznie nawołuje do popełnienia zbrodni, podlega karze pozbawienia wolności do lat 3. [art. 255 par. 2 k.k.]

Kto publicznie znieważa [...] godło, sztandar, chorągiew, banderę, flagę lub inny znak państwowy, podlega grzywnie, karze ograniczenia wolności albo pozbawienia wolności do roku. [art. 137 par. 1 k.k.]

Z łatwością można sobie wyobrazić popełnienie powyższych przestępstw wyłącznie przez odwołanie się przez sprawcę do wypowiedzi innych osób. Okoliczność, kto jest autorem przestępczych wypowiedzi, nie jest bowiem istotna dla ponoszenia odpowiedzialności karnej; w wypadku jej przypisania ważne jest, kto i w jakim celu decyduje się na zakazane prawem użycie języka. Oczywiste jest przy tym, że wszystkie powyższe przestępstwa lingwistyczne mogłyby zostać popełnione również w formie bezpośredniej, a więc na skutek sformułowania przez sprawcę w pełni autorskich wypowiedzi. Co oczywiste, rozróżnienie lingwistycznych przestępstw bezpośrednich i pośrednich ma sens wyłącznie względem formy przestępczej „z użycia języka”.

Linguae crimines $\mathrm{z}$ powodzeniem mogą być również klasyfikowane z zastosowaniem kryterium dobra prawnego, w które godzą. Nie wdając się w szczegółową analizę tychże dóbr, w ogólności przyjąć można, że przestępstwa lingwistyczne dzielą się na publiczne i indywidualne. Pierwsze z nich uderzają w dobra zbiorowe, ogólnospołeczne i ogólnopaństwowe, drugie zaś - 
w dobra jednostkowe. Przykład lingwistycznego przestępstwa o charakterze publicznym bez trudu odnaleźć można wśród przepisów k.k.s.:

Podatnik, który składając organowi podatkowemu, innemu uprawnionemu organowi lub płatnikowi deklarację lub oświadczenie, podaje nieprawdę lub zataja prawdę albo nie dopełnia obowiązku zawiadomienia o zmianie objętych nimi danych, przez co naraża podatek na uszczuplenie, podlega karze grzywny do 720 stawek dziennych albo karze pozbawienia wolności, albo obu tym karom łącznie. [art. 56 par. 1 k.k.s.]

Celem powyższej regulacji jest zapewnienie prawnej ochrony bonum commune postrzeganego jako stabilność i płynność finansowa państwa, z której czerpać korzyści mogą wszyscy jego obywatele. Lingwistyczne przestępstwa indywidualne godzą natomiast w dobra konkretnych podmiotów, jak np. przestępstwo zniewagi penalizowane w art. 216 k.k.:

Kto znieważa inną osobę w jej obecności albo choćby pod jej nieobecność, lecz publicznie lub w zamiarze, aby zniewaga do osoby tej dotarła, podlega grzywnie albo karze ograniczenia wolności. [art. 216 par. 1 k.k.]

Zaproponowane typologie linguae crimines nie mają charakteru wyczerpującego, jednak już na ich podstawie można sformułować ogólny wniosek badawczy, zgodnie z którym przestępstwa lingwistyczne stanowią istotną część czynów przestępczych uregulowanych w polskich ustawach karnych. Zrównanie użycia języka i odmowy jego użycia z innymi czynnościami wykonawczymi świadczy o docenianiu przez ustawodawcę wagi języka jako naturalnej dyspozycji człowieka, a także leżącej w języku potencji do bycia nośnikiem wartości i antywartości prawnych.

\section{Podsumowanie}

Pojęcie przestępstwa lingwistycznego nie było dotychczas znane zarówno na płaszczyźnie językoznawstwa, jak i na płaszczyźnie nauk prawnych; nie operują nim ani sądy, ani inne organy czy osoby powołane do stosowania przepisów prawa. Postuluję wprowadzenie tego pojęcia na grunt naukowy celem rozróżnienia przestępstw popełnianych słowem od innych typów czynów zabronionych, a tym samym dostrzeżenia znaczenia słowa mówionego i pisanego, a także zjawiska milczenia w szeroko rozumianych procesach związanych z przestępczością. Wyjście od tej definicji umożliwi ponadto przeprowadzenie dalszych szczegółowych badań nad typologiami przestępstw 
tego rodzaju oraz - w aspekcie językoznawstwa diachronicznego i kulturoznawstwa - nad zmianami słów i wyrażeń, których artykulacja czy napisanie wiązały się z sankcją karną w poszczególnych okresach obowiązywania prawa. Zasadne byłoby również rozszerzenie analiz teoretycznych o problematykę wykroczeń lingwistycznych i wykroczeń skarbowych, a także form zjawiskowych i stadialnych ogółu czynów przestępczych (w tym zwłaszcza formy zjawiskowej podżegania do przestępstwa, mającej w większości przypadków charakter językowy).

Językoznawcze badania linguae crimines mogłyby też opierać się na metodzie indywidualnych przypadków. Na jej kanwie biegli językoznawcy sądowi $\mathrm{z}$ dużą dozą prawdopodobieństwa mogliby wskazywać - na podstawie danych płynących z analiz idiolektów - czy dane przestępstwo lingwistyczne zostało czy też nie zostało popełnione przez określoną osobę, a następnie wiedzę tę przekazać sądowi, który podejmie w tym przedmiocie ostateczną decyzję.

Rozpowszechnienie typologii przestępstw lingwistycznych w opracowaniach naukowych i popularnonaukowych może mieć nadto dodatni wymiar społeczny, polegający na poszerzaniu odpowiedzialności za słowa w kontekście nie tylko moralnym, ale również prawnym. Uważna obserwacja aktualnego dyskursu publicznego upoważnia do wniosku, że wielu obywateli nie ma woli poczuwać się do takiej odpowiedzialności.

\section{Bibliografia}

Źródta (wraz ze stosowanymi skrótami)

k.k. - Ustawa z dnia 6 czerwca 1997 r. Kodeks karny, Dz.U. Nr 88, poz. 553 z późn. zm.

k.k.s. - Ustawa z dnia 10 września 1999 r. Kodeks karny skarbowy, Dz.U. Nr 83, poz. 930 z późn. zm.

\section{Literatura}

Austin John (1993), Mówienie i poznawanie. Rozprawy i wykłady filozoficzne, przeł. Bohdan Chwedeńczuk, Warszawa.

Bojarski Marek, Giezek Jacek, Sienkiewicz Zofia (2020), Prawo karne materialne.

Czesść ogólna i szczególna, Warszawa.

Everett Daniel (2018), Język jako narzędzie kultury, Kraków.

Gardocki Lech (2019), Prawo karne, Warszawa.

Konarska-Wrzosek Violetta, Marek Andrzej (2019), Prawo karne, Warszawa.

Kurzowa Zofia i in. (2008), Słownik synonimów, Warszawa. 
Morawski Lecz (2004), Wstęp do prawoznawstwa, Toruń.

Nazar-Gutowska Katarzyna (2012), Groźba bezprawna w polskim prawie karnym, Warszawa.

Pieńkos Jerzy (1999), Podstawy juryslingwistyki. Język w prawie - prawo w języku, Warszawa.

Stanik Jan (2013), Psychologia sadowa, Warszawa.

Stefański Ryszard, red. (2020), Kodeks karny. Komentarz, Warszawa.

Wróbel Włodzimierz, Zoll Andrzej (2014), Polskie prawo karne. Część ogólna, Kraków.

Zagrodnik Jarosław i in. (2019), Proces karny, Warszawa.

Zieliński Maciej (2017), Wykładnia prawa. Zasady - reguly - wskazówki, Warszawa.

Anna Falana-Jafra

\section{A Linguistic Crime as an Offence of Using or Failing to Use Language. Selected Typologies of Linguistic Crimes Penalised in Polish Criminal Laws}

The aim of the article is to formulate a definition of linguistic crimes as a specific type of crimes penalised in Polish criminal laws and to categorise them according to the following criteria: the nature of the perpetrator's enforcement activities; the use of language or failure to use it; the length of the linguistic enforcement activities; the authorship of statements; the nature of the legal good to be protected. Human behaviour, which is legally classified as a linguistic offence, is performative in nature and therefore has the legal effect of making the offender criminally responsible and of imposing criminal sanctions on him/her by the competent state authorities. In the article, the performative function of language will be extended to include the notion of passive performativity, resulting from an offence committed as a result of the failure to use language in situations where its use is required by the legal system.

KEYWORDS: linguistic crime; use of language; silence; criminal law.

mgr Anna Falana-Jafra [ORCID 0000-0002-9901-1791] - magister prawa i filozofii, obecnie doktorantka w dyscyplinie językoznawstwo na Uniwersytecie Humanistyczno-Przyrodniczym im. Jana Długosza w Częstochowie; zainteresowania badawcze: juryslingwistyka w zakresie polskiego języka prawa i polskiego języka prawniczego, językoznawstwo kognitywne. 